\title{
A disciplina do amor
}

\author{
Aquele abraço, de Marcelo Maldonado
}

André Rosa*

"Meu carinhoso e meigo rapaz,

Não cores, que meu és para sempre!

[...]

Não temas outros de riso atroz,

Pois em nós mesmos nos desdobramos:

Tal qual duas partes de uma noz,

Sob a mesma casca nos achamos".

Aleksánder Púchkin

Corria o ano de 1986, quando o caos e a aleatoriedade atingiram em cheio Lucas, protagonista de Aquele abraço (2017), primeiro romance do carioca Marcelo Maldonado. Aluno recém-chegado em uma instituição militar, ambiente em que se desenvolve a maior parte do enredo, ele, um menino de doze anos, descobre suas primeiras perguntas, seus primeiros medos e também seus primeiros pecados, como nos sugere o uso, como primeira epígrafe do livro, do claríssimo Salmo 51: "Porque eu conheço as minhas transgressões, e meu pecado está sempre diante de mim".

Narrado em primeira pessoa, como um diário, Aquele abraço é dividido em 34 capítulos que se desenvolvem em sintonia com as 
descobertas feitas por Lucas, personagem-narrador. A narrativa é atravessada por uma tempestade de sentimentos, medos, sorrisos e experimentações que, pouco a pouco, se desnudam aos olhos do leitor. Ambientada principalmente no Colégio Militar da Tijuca, mostra que os estudantes de uniformes caquis e calças rubras não demoraram a descobrir que ali "aprenderiam a ser homens", como anunciava a voz alta e ríspida de um sargento que se dirigia aos novatos como "bichos" - coisa que o protagonista não compreendeu de imediato se denotava promessa ou ameaça.

A amizade cada vez mais próxima entre Lucas e o colega Victor logo vira alvo de comentários maldosos: a sexualidade de ambos é questionada e os dois passam a ser vistos como "namoradinhos". Antes disso acontecer, não percebiam os olhares e cochichos cínicos daquele recinto, que o escritor Caio Fernando Abreu teria chamado de "deserto de almas" - como no conto "Aqueles dois", de Morangos mofados, ao qual Maldonado muito provavelmente presta tributo -, em que a amizade e o afeto são julgados e condenados pelos pretensos guardiões da moralidade.

O ambiente militar, quase sempre hostil às emoções de Lucas, interfere no convívio dos dois amigos, que se intensifica para além dos muros do colégio. É precisamente nesse momento que o vínculo entre eles chega a três circunstâncias essenciais: a aproximação dos mundos, quando passam a frequentar a casa um do outro e, assim, a se entregar ao mundo um do outro, com Victor descobrindo a música de Lucas e Lucas descobrindo o futebol de Victor; a descoberta do corpo, quando experimentam, juntos, a masturbação e o toque antes proibido; e, por fim, a negação, quando Victor, confuso e agressivo, rejeita em si uma experiência homossexual que já aconteceu. 
Tanto quanto o conto de Caio Fernando Abreu, o romance é atravessado por um tema musical que evoca o sentimento que há entre os dois amigos. Da mesma forma que em "Aqueles dois" o bolero "Tú me acostumbraste", cantado por Caetano Veloso, comove os amigos Raul e Saul, em Aquele abraço há um momento em que Lucas descreve sua visita à casa de Victor, quando os dois trocam olhares enquanto ouvem Nat King Cole cantar "When I fall in love", tema da série Anos dourados, que, vista pelos dois, possibilitou que se conhecessem. Na verdade, o romance é perpassado pela música, presente também pela famosa gravação de "Take five" pelo Dave Brubeck Quartet e pelas lições de Chopin a Schubert que Lucas recebe de sua tia Lara - e que tanto enchem os olhos de Victor.

Um terceiro ponto em comum com o conto do autor gaúcho é o modo como a amizade se estabelece, quase que uma citação. Em ambas as narrativas, os dois se encontram em um ambiente novo, respectivamente, um escritório e uma escola. Nas duas situações, um deles demonstra cansaço por ter ficado até tarde assistindo à televisão. Em "Aqueles dois", Saul havia assistido ao filme Infâmia - sobre duas amigas próximas que são vistas como namoradas e por isso têm seu negócio arruinado -, que Raul conhecia e gostava muito. Em Aquele abraço, Lucas havia ficado até tarde assistindo a Anos dourados, que Victor também acompanhava.

Por outro lado, em direção oposta à do conto "Aqueles dois", em que a natureza da relação entre os amigos Raul e Saul não se explicita, os personagens de Marcelo demonstram transparência: mesmo sob a ótica turva de dois garotos que ainda não sabem ao certo o que são, o primeiro gozo, por exemplo, é descrito com clareza. O mesmo ocorre ao toque entre os corpos, que se completam como as duas partes de uma noz que se encontram sob a mesma 
casca, conforme descrito no poema de Púchkin que serve de epígrafe a esta resenha.

Intimista, esse romance de formação (ou, como chamam em alemão, Bildungsroman) tematiza contradições do humano que até hoje não foram totalmente superadas, com seus amores e ódios, como dois lados exatos de um mesmo objeto. Victor se junta a seus algozes para atacar Lucas e, de certo modo, atacar a si mesmo e a seu pecado. Encarna as contradições de uma sexualidade há muito observada e descrita por diversos ângulos pela literatura, que dela oferece ficções absolutamente reais. Se tanto em Caio Fernando Abreu quanto em Maldonado a homossexualidade é recebida com a ira dos que estão em volta, na obra inacabada Niétotchka Niezvânova Dostoiévski descreve uma relação lésbica entre duas crianças com absoluta naturalidade, como se os leitores do século XIX estivessem plenamente abertos a essa forma de amor, tanto que as diferenças desaparecem por si próprias.

Em sua aparição como romancista, Marcelo Maldonado enfrenta com coragem um dilema que acompanha o homem desde a queda de Adão e, por mais paradoxal que pareça, permanece absolutamente contemporâneo. Igualmente notável é o texto em si, primoroso a ponto de nos fazer pensar em outra suposta contradição: a estreia de um escritor já pronto. 